\title{
Grammatical collocations and verb- particle constructions in Brussels French: a corpus-linguistic approach to transfer
}

Article

Accepted Version

Treffers-Daller, J. (2012) Grammatical collocations and verbparticle constructions in Brussels French: a corpus-linguistic approach to transfer. International Journal of Bilingualism, 16 (1). pp. 53-82. ISSN 1367-0069 doi:

https://doi.org/10.1177/1367006911403213 Available at https://centaur.reading.ac.uk/20642/

It is advisable to refer to the publisher's version if you intend to cite from the work. See Guidance on citing.

To link to this article DOI: http://dx.doi.org/10.1177/1367006911403213

Publisher: SAGE

All outputs in CentAUR are protected by Intellectual Property Rights law, including copyright law. Copyright and IPR is retained by the creators or other copyright holders. Terms and conditions for use of this material are defined in the End User Agreement.

www.reading.ac.uk/centaur 
Central Archive at the University of Reading

Reading's research outputs online 
A corpus-linguistic approach to transfer

Grammatical collocations and verb-particle constructions in Brussels French: a corpuslinguistic approach to transfer ${ }^{1}$

International Journal of Bilingualism (2011, in press). doi:10.1177/1367006911403213

Jeanine Treffers-Daller (UWE Bristol)

Department of English, Linguistics and Communication

Faculty of Creative Arts, Humanities and Education

Frenchay Campus

Coldharbour Lane

Bristol BS16 1QY

Tel. 0117-3282390

Email: Jeanine.treffers-daller@uwe.ac.uk

Running head

A corpus-linguistic approach to transfer

\footnotetext{
${ }^{1}$ I gratefully acknowledge financial support received from the School of Humanities, Languages and Social Sciences at UWE Bristol for a term's leave, which made it possible to collect and analyse the data. I am very grateful to Kate Beeching for making her corpus of modern spoken French available and for help in analysing examples from this corpus, and to Michel Francard and his team for giving me access to the VALIBEL database. I am also indebted to Kate Beeching, Geert Booij, Richard Coates, Raymond Mougeon, Sera de Vriendt and one anonymous reviewer for their detailed comments on earlier versions. All remaining errors are mine.
} 
A corpus-linguistic approach to transfer

\begin{abstract}
This paper shows how a corpus-linguistic approach to transfer based on Jarvis (2000), Jarvis \& Pavlenko (2008) and Mougeon, Nadasdi \& Rehner (2005) can help to disentangle internal and external explanations in language variation and change. The focus of the study is on grammatical collocations (Granger \& Paquot, 2008) such as chercher après "to search for" and verb-particle constructions (VPCs) such as recevoir dehors "to get out" in Brussels French. The occurrence of such patterns in Romance varieties is often linked to contact with Germanic varieties, in which VPCs are common. In the current paper I discuss the syntactic and semantic properties of both types of constructions and argue they are to be considered as replications of grammatical use patterns (Heine \& Kuteva, 2005) from the contact language, the regional variety of Dutch. Proof for covert transfer from Dutch is found through a detailed comparison of the frequency of the patterns in a range of spoken and written corpora.
\end{abstract}

Keywords: language contact, transfer, verb-particle constructions, collocations, replication, French 


\section{Introduction}

This article aims to show in the first place that it is possible to disentangle the role of internal and external factors in language change if a corpus-linguistic approach is taken and a comparison is made of the frequency of the phenomena under study in a variety of corpora. Jarvis (2000, p. 246) points out that L1 transfer is too often treated as a "you-know-it-whenyou-see-it" phenomenon, and calls for more methodological rigour in the study of transfer, as this may help to resolve the rather unsettling amount of confusion in the field surrounding the role of transfer in L2 acquisition. The second aim of this study is to bring together approaches from different fields to the study of this issue. Researchers in Second Language Acquisition and Contact-Induced Language Variation and Change both often address the issue of transfer without being aware of either the methods that are being followed or the results that were obtained in each other's field. It is particularly interesting that researchers from both fields have called for a more rigorous (Jarvis 2000) or more adequate (Mougeon, Nadasdi \& Rehner, 2005) approach to the study of transfer and have proposed very similar solutions to the issue of what constitutes evidence for this phenomenon (see Table 1). Jarvis \& Pavlenko (2008) propose that three kinds of evidence are needed in arguing the case for transfer: Intralinguistic homogeneity (to what extent learners with the same L1 behave in a uniform manner when using L2); intergroup heterogeneity (to what extent learners with different L1s perform in a different way in the L2) and crosslinguistic performance congruity (the learners' use of some L2 feature parallels their use of that feature in L1).

This approach is similar to the steps that researchers in the field of Language Variation and Change recommend taking if one wants to argue that an innovative feature in a contact variety is the result of intersystemic contact (see Table 1). Mougeon, Nadasdi \& Rehner (2005) argue that, in step 1, researchers should establish whether there is equivalence between the productions of the speakers in both languages, which corresponds to Jarvis \& 
Pavlenko's third criterion. In Step 2 alternative explanations such as overgeneralisation or regularisation are explored and in step 3 a comparison with data from other sources is made. These two steps in the process are covered by Jarvis \& Pavlenko's second criterion (intergroup heterogeneity).

Table 1. Overview of similarities between approaches to transfer in SLA and contact-induced language variation and change.

\begin{tabular}{|c|c|}
\hline $\begin{array}{l}\text { Jarvis (2000) } \\
\text { Jarvis \& Pavlenko (2008) }\end{array}$ & Mougeon, Nadasdi \& Rehner (2005) \\
\hline Intragroup homogeneity & $\begin{array}{l}\text { Distribution of feature among recipient language speakers } \\
\text { (+ correlation with degree of contact with source language) } \\
\text { (step 4) }\end{array}$ \\
\hline Intergroup heterogeneity & $\begin{array}{l}\text { a) Comparison with related varieties which have } \\
\text { undergone influence from the same source } \\
\text { b) Comparison with varieties which have not } \\
\text { undergone this influence (step 2); } \\
\text { c) Identification of alternative explanations (e.g. } \\
\text { universal simplificatory patterns) (step 3) }\end{array}$ \\
\hline $\begin{array}{l}\text { Crosslinguistic performance } \\
\text { congruity }\end{array}$ & $\begin{array}{l}\text { Identification of equivalent features in productions of the } \\
\text { speakers in both languages (step 1) }\end{array}$ \\
\hline
\end{tabular}

In step 4, Mougeon et al. recommend studying whether or not the distribution of an innovation is linearly correlated with the level of contact with the source language. If so, this is an argument in favour of transfer-based explanations, even though the authors point out that this correlation may be much weaker if variants are widely used in the recipient language speech community. Jarvis \& Pavlenko (2008) do not discuss this issue in great detail but 
mention the fact that individual variation in knowledge of or contact with the source language can be a reason for low levels of intragroup homogeneity among recipient language users. This is not likely to be the case if the feature has undergone a process of diffusion (see Mougeon et al., 2005, p. 104).

The approach sketched above will be used in the analysis of grammatical collocations such as regarder après "look for" or chercher après "look for" in Brussels French, the variety of French spoken in Brussels ${ }^{\mathrm{i}}$. The term GRAMMATICAL COLLOCATION is borrowed from Granger \& Paquot (2008, p. 33), who distinguish lexical collocations, which consist of two lexical words, such as strong tea or dispel fear, from grammatical collocations, which are made up of a lexical word and a grammatical word, e.g. aim at or afraid that.

Prior to the discussion about the source of the constructions under study, I aim to clarify whether the second element in the collocations (après "after", (en de)hors de "out (of)" and en bas (de) "down") is a preposition, an adverb or a particle. Talmy (1985) uses the term "satellite" for particles that are part of phrasal verbs in e.g. English, as well as for the separable and inseparable prefixes found in the Germanic languages. With Talmy (1985, p. 102) I assume that prepositions are to be distinguished from satellites, because prepositions disappear when the complement is omitted, but satellites remain in place. As Talmy shows, in I ran out of the house, for example, ran is followed by the satellite out as well as the preposition of, but the satellite out can also appear alone, as in he ran out. He notes that the verb root together with its satellites forms a constituent in its own right, the 'verb complex'. Other authors use the term verb-particle construction (VPC). As the term "particles" is more widely used than "satellites" among researchers in the field, I prefer to use the former.

The key question I will focus on in this paper is to what extent the constructions under study are characteristic for this variety of French only or more commonly found in other varieties of French, and whether there is evidence for any influence from Dutch in these 
constructions. Comparing isolated examples from different periods in the history of French or from different speakers is not helpful, because these provide us only with a confusing range of structures, but not with criteria that can help decide whether internal or external explanations are most plausible. New light can be thrown on the issue if we adopt a corpuslinguistic approach, making a comparison of the frequency of the phenomena in different corpora along the lines of the method proposed by Jarvis (2000), Jarvis \& Pavlenko (2008) and Mougeon et al. (2005).

Transfer will be assumed to have played a role in the occurrence of these structures in Brussels French, if the patterns

a) are widespread among the target group of bilingual speakers in Brussels and not an isolated incident (intragroup homogeneity);

b) are more frequent in the variety of French used by Dutch-French bilinguals than among varieties of French that are not currently in contact with a Germanic language or are in less direct contact Dutch, such as varieties of Belgian French from Wallonia (intergroup heterogeneity);

c) are a common feature in the performance of source language speakers, i.e. Dutch (crosslinguistic performance congruity);

d) cannot be explained as internal developments;

e) are found most frequently among speakers with the highest level of contact with the source language, Dutch.

This does not mean that transfer is the only reason: the occurrence of a particular grammatical collocation may well be the result of multiple causation (Thomason \& Kaufmann, 1988): i.e. transfer and internal causes can contribute together to the emergence or diffusion of a pattern (see also Heine \& Kuteva, 2005). 
The structure of the paper is as follows. First I will introduce a number of key concepts of contact-induced change and transfer (section 2). The next section (3) deals with the criteria Jackendoff (2002) uses to distinguish prepositions and particles, and these are subsequently applied to the constructions found in Brussels French, with a view to establish whether they are VPCs or not. In section 4 the focus is on VPCs in Romance-Germanic contact situations. Section 5 presents an overview of the methodology and section 6 focuses on the results of the analyses of different data sets. Section 7 offers a discussion and a conclusion.

\section{Contact-induced change, transfer and replication}

For the purposes of the present paper, contact-induced change is defined as "the adoption of a structural feature into a language as a result of some level of bilingualism in the history of the relevant speech community" (Matras \& Sakel, 2007, p. 1). Following Grosjean (this volume) we will consider the occurrence of a grammatical collocation to be an example of TRANSFER, if it can be shown that it is static in that it represents a permanent trace of one language on the other, and not a dynamic phenomenon which is linked to processing ${ }^{\text {ii }}$. For the latter Grosjean proposes to use the term INTERFERENCE. Sharwood Smith \& Kellerman $(1986$, p. 1) use the term transfer in a similar way to refer to the "processes that lead to the incorporation of elements from one language into another".

The distinction between OVERT and COVERT TRANSFER is also relevant for the current paper. Mougeon et al. (2005, p. 102) reserve the former for qualitative developments in the recipient language, whereas the latter consists only in a quantitative development, namely a marked increase in the frequency of a feature. Whether or not the Brussels French collocations represent a case of overt or of covert transfer will need to be established through a thorough comparison with a range of sources. 
As I have argued elsewhere (Treffers-Daller, 1999), the influence of Dutch on Brussels French manifests itself mainly in the use of reinterpreted and/or restructured French words, and much less in the importation of Dutch language forms. This is to be expected as the influence from Dutch on French is the result of a process Thomason \& Kaufman (1988, p. 115) call INTERFERENCE THROUGH SHIFT. It is therefore unlikely that Dutch prepositions or adverbs are imported into Brussels French collocations, but the structural patterns in which après, dehors and en bas occur are potentially copied from Dutch. This contrast is clearly captured in the distinction Matras \& Sakel (2004) make between MATTER REPLICATION (the replication of morphological material and its phonological shape) and PATTERN REPLICATION: "the organisation, distribution and mapping of grammatical or semantic meaning, while the form itself is not borrowed" (Sakel, 2007, p. 15).

As Heine \& Kuteva (2005, p. 40) have pointed out, when grammatical use patterns are replicated, the new structure in the recipient language is not entirely new in most cases: it often builds on some structure that is present in the source language but constitutes only a minor use pattern. Through the process of replication this minor use pattern then becomes a major use pattern. It is entirely possible that this is also the case in the collocations under study here, and for this reason it is very important to include historical data in the analysis.

\section{Distinguishing prepositions and particles}

As it is important to establish whether the phenomena under study are prepositions, particles or adverbs, I will first review the most important criteria used to differentiate particles and prepositions, and then apply these criteria to the Brussels French data.

Dehé, Jackendoff, McIntyre \& Urban (2002, p. 3) define particles in the following way: 
A corpus-linguistic approach to transfer

"an accented element which is formally (and, often, semantically) related to a preposition, which does not assign case to a complement and which displays various syntactic and semantic symptoms of what may informally be called a close relationship with a verb, but without displaying the phonological unity with it typical of affixes."

Jackendoff (2002, p. 69) notes that the class of particles is for the most part homophonous with prepositions, but suggests there are clear criteria to distinguish the two. First of all, with intransitive verbs, the particle can serve as the only complement, as in (1), but this is not possible with prepositions such as from, as (2) illustrates. Prepositions can of course be left stranded at the end of the sentence, when the complement has been moved, as in (3).

(1) George grew up (Jackendoff, 2002, p. 69)

(2) *The branch grew from.

(3) The tree the branch grew from.

With transitive verbs, the particle can appear on either side of the complement, as in $(4 \mathrm{a} / \mathrm{b})$, but prepositions can only appear on the left, as (5a/b) illustrate.

(4a) Bill put out the garbage. (Jackendoff, 2002, p. 69)

(4b) Bill put the garbage out. (Jackendoff, 2002, p. 69)

(5a) The branch grew from the tree.

(5b) *The branch grew the tree from. 
A corpus-linguistic approach to transfer

When they appear on the left of the complement, particles look like prepositions, but several tests show that they are different. Thus, cleft constructions are possible with PPs (6a) but not with particles and their complements (6b). Similarly, Wh-movement with pied piping is possible with PPs, as we can see in (7a), but not with particles and their complements (7b).

(6a) It was from the tree that the branch grew.

(6b) *It was out the garbage that Bill put.

(7a) From which tree did the branch grow?

(7b) * Out which garbage did Bill put?

While the properties of VPCs in the Germanic languages are well known (Booij, 2002; 2010), far less attention has been paid to such constructions in the Romance languages, which are often assumed not to possess VPCs (Dufresne, Dupuis \& Tremblay, 2003, p. 33; Tremblay, 2005, p. 263). In this article I can only summarise a few key syntactic characteristics of the constructions under study here, but more details about the historical development of the distinction between prefixes, prepositions and (adverbial) particles in French can be found in Dufresne et al. (2003), Kopecka (2006) and Marchello-Nizia (2002). I will not deal with the prosodic criteria Dehé et al. (2002) use to distinguish prepositions and particles. As Germanic languages are stress-timed whereas French is a syllable-timed language (Abercrombie, 1967), it is unlikely that the stress patterns associated with particles in the Germanic languages and the Romance languages are the same.

In Brussels French prepositions can be combined with a variety of verbs in ways that are not attested in dictionaries of Standard French, such as the Trésor de la Langue Française Informatisé (http://atilf.atilf.fr/tlf.htm). Baetens Beardsmore (1971, p. 210) notes that verbs 
which are transitive in metropolitan French are sometimes accompanied by prepositions, as in chercher après "to look for", and that prepositions are also used as adverbs more often in Brussels French than in French as spoken in France ${ }^{\mathrm{iii}}$. In this study the focus will be on collocations of verbs with après "after", en bas (de) "down" and (en) (de)hors (de) "out of", which are often argued to be transferred from Dutch (e.g. Baetens Beardsmore, 1971), because VPCs are very common in Germanic languages. The Dutch translation equivalents zoeken naar "to look for" and naar beneden vallen or neervallen "to fall down" from my Brussels French corpus are often seen as sources for the Brussels French constructions in $(8 \mathrm{a} / \mathrm{b})$ and $(9 \mathrm{a} / \mathrm{b} / \mathrm{c})$. These examples show that après and en bas can be used in different ways. In (8a) preposition après is followed by a complement, but in (8b) there is no overt complements.

(8a) Il cherche encore toujours après sa petite grenouille.

'He is still looking for his little frog.' (corpus JTD, informant 3)

(8b) Mais le chien court après et les fait tomber (corpus JTD, informant 22)

'But the dog runs after (them) and makes them fall.'

In (9a) en bas de can be seen as a compound preposition (Jones, 1996) or if one uses Talmy's (1985) framework, as a sequence of the satellite (particle) en bas "down" and the preposition de "of". In (9b) it is an adverbial phrase which does not take a complement.

(9a) Son chien il tombe en bas de la fenêtre.

'His dog he falls down from the window.' (corpus JTD, informant 18)

(9b) En une fois il ne sait plus se tenir et il tombe en bas (corpus JTD, informant 6)

'All of a sudden he cannot hold on anymore and he falls down.' 
A corpus-linguistic approach to transfer

Examples (10a) and (10b) are clearly different from each other in that dehors is part of a compound preposition in (10a) $)^{\text {iv }}$, but an adverb in (10b). In Dutch there is a wide range of verbs with separable prefixes such as uit-vallen "to fall out" (Booij, 2002; 2010), which could have formed the model for the occurrence of tomber en dehors in (10a).

(10a) Le gamin lui il tombe en dehors de l'arbre. (corpus JTD, informant 19)

'The boy, he falls out of the tree.'

(10b) Il va dehors et appelle la grenouille. (corpus JTD, informant 11)

'He goes out and calls the frog.'

The first question that needs to be answered is whether or not the structures under study here constitute examples of verb-particle constructions. The results of the tests proposed by Jackendoff (2002) show that most constructions under study here are not VPCs, because they allow for clefting and wh-movement with pied piping (11-13). This indicates that in these constructions après, (en de) hors (de) and en bas de are best seen as prepositions or adverbs, and not as particles.

(11a) C'est après sa grenouille que le garçon cherche.

'It is after his frog that the boy is searching.'

(11b) Après quelle grenouille le garçon cherche-t-il ?

'After which frog is the boy searching?'

(12a) C'est hors de la maison que le garçon est sorti.

'It is out of the house that the boy went.' 
A corpus-linguistic approach to transfer

(12b) Hors de quelle maison le garçon est-il sorti ?

'Out of which house did the boy go ?'

(13a) C'est en bas de la fenêtre qu'il est tombé.

'It is down the window that he fell.'

(13b) En bas de quelle fenêtre est-il tombé ?

'Out of which window did he fall ?'

The Brussels French constructions differ in this respect from the Canadian ones mentioned by Chevalier \& Long (2005), of which (14a) is an example. As we can see in (14b/c) shutter off does not allow for clefting or pied piping.

(14a) J'ai shutté off la light (Chevalier \& Long, 2005, p. 207)

'I shut the light off.'

(14b) *C'est off la light que j'ai shutté

It is off the light that I shut.

'I shut the light off.'

(14c) *Off quelle light est-ce que j'ai shuttée?

Off which light did I shut?

'Which light did I shut off?' 
A corpus-linguistic approach to transfer

Although we have just seen that en bas it is not a particle, it is interesting that it can be placed on either side of its complement, as (9a), repeated here as (15a), and (15b) show. ${ }^{\mathrm{v}}$

(15a) Son chien il tombe en bas de la fenêtre.

'His dog he falls down from the window.' (corpus JTD, informant 18)

(15b) Le chien tombe déjà de la fenêtre en bas.

'The dog already falls down from the window.' (corpus JTD, informant 8)

By contrast, we find après only to the left of its complement, as can be seen in (16), unless the complement has been moved or replaced with a pronoun, as in (17). In examples such as (17) après is a stranded preposition because the dative clitic lui "him" is the complement of après.

(16) *Le garçon cherche la grenouille après

The boy looks the frog for

'The boy looks for the frog.'

(17) Les abeilles lui courent après (corpus JTD, informant 23)

The bees him run after

'The bees run after him.'

If dehors is used in combination with sortir 'to go out' (see 18), it only appears to the left. In combinations with other verbs, such as recevoir "to get", it can appear on the right as well (see below for a discussion of example 20). 
A corpus-linguistic approach to transfer

(18) * Le garçon est sorti de la maison (en) (de)hors

The boy is left of the house out

'The boy left the house.'

There are, however, also other combinations with après, dehors and en bas which are clearly different from the ones discussed so far. Baetens Beardsmore (1971) notes that en bas can be combined with a range of verbs, such as payer en bas "to pay off", secouer en bas "to shake off" and couper en bas "to cut off". Collocations with dehors include chercher dehors "search out, take out" and couper dehors "to cut out". While on the surface en bas in (19) resembles a preposition, it cannot be moved to the front in a cleft construction (19a), nor is pied piping of the PP allowed (19b). Thus, according to Jackendoff's (2002) criteria, en bas is a particle in this construction. Together with the verb secouer "to shake" forms the VPC secouer en bas "to shake off" in (19).

(19) Secoue un peu la crasse en bas sur le grattoir (Vekemans, 1963 ; in Baetens

Beardsmore, 1971 , p. 262)

Shake a bit the dirt off on the scraper.

'Shake the dirt off the scraper.'

(19a) *C'est la crasse en bas que tu secoues

It is the dirt down that you shake

'It is the dirt that you shake off.'

(19b) *Quelle crasse en bas secoues-tu?

Which dirt off did you shake

'Which dirt did you shake off?' 
A corpus-linguistic approach to transfer

For the same reasons, dehors in (20) is a particle, and it forms a VPC with recevoir "to get". As (20a/b) demonstrate, clefting and pied piping are not possible with this construction.

(20) Je ne sais pas recevoir le bouchon dehors (De Vriendt, 2004, p. 34)

'I cannot get the (fuel) cap out.'

(20a) *C'est le bouchon dehors que j'ai reçu

It is the fuel cap out that I got

'It is the fuel cap that I got out.'

(20b) *Quel bouchon dehors ai-je reçu?

Which cap out did I get

'Which cap did I get out?'

It is possible to separate après from the verb, as in (21), where two PPs, dans le bois "in the forest" and avec son chien "with his dog", appear between the verb chercher and the preposition après.

(21) Il va même chercher dans le bois avec son chien après sa grenouille (corpus

JTD, informant 22)

'He even goes looking in the forest with his dog for his frog.'

While the issue cannot be explored in much detail here, the word order in (21) is not common in metropolitan French. In French from France adjuncts such as dans le bois "in the forest" 
A corpus-linguistic approach to transfer

and avec son chien "with his dog" normally follow the direct object sa grenouille "his frog" or a prepositional phrase which is closely linked to the verb, such as après sa grenouille "after his frog" (Judge \& Healey, 1985, p. 403; see also Magnus (2007) for further details on the contrasts between Dutch and French word order). Therefore speakers of metropolitan French would probably prefer the word order given in (21a):

(21a) Il va même chercher (après) sa grenouille dans le bois avec son chien.

'He even goes looking for his frog in the forest with his dog.'

It is possible that the word order in (21) is influenced by Brussels Dutch, which allows for the insertion of several adjuncts before the preposition which forms a collocation with the verb. The word orders in (21b) and (21c) are both possible in Dutch.

(21b) Hij zoekt zelfs in het bos met zijn hond naar de kikker.

'He even looks in the forest with his dog for the frog.'

(21c) Hij zoekt zelfs met zijn hond in het bos naar de kikker.

'He even looks with his dog in the forest for the frog.'

A few words also need to be said about the semantics of the constructions. The collocations form lexicalised patterns, i.e. a particular meaning is found to be in regular association with this construction. The meanings of Brussels French collocations such as payer en bas "to pay off" (Baetens Beardsmore, 1971, p. 262) or recevoir dehors "to get out" (De Vriendt, 2004, p. 34) are not very transparent to speakers unfamiliar with this variety of 
French and can often only be understood by those familiar with the Dutch translation equivalents.

The addition of après (whether used as a preposition or as an adverb) to courir in (21) changes the meaning of the verb from "run" to "pursue/chase" and crier après means "to call (for)", which is different from crier "to cry". In both cases, there is a more formal equivalent for these verbs, namely poursuivre "pursue/chase" and appeler "to call (for)". The addition of après also changes the subcategorisation frame of the verb so that it can be used in combination with an object (courir après quelqu'un/quelque chose "to run after someone/something"; crier après quelqu'un/quelque chose "to call for someone/something").

The addition of en bas (de) to the path verb tomber as in $(20 \mathrm{a} / \mathrm{b})$ appears to be redundant, but as one reviewer has pointed out, the expression en bas adds a precision to the meaning of the verb: it can be functional in some contexts, as for example descendre en bas can be used to refer to going down to the ground floor as opposed to going down to the first floor of a building.

\section{Verb-particle constructions in Romance-Germanic contact situations}

While verb-particle constructions are commonly found in Germanic languages, there is some evidence for their existence in Romance languages too. Iacobini \& Masini (2006, p. 169) show that VPCs such as andare dentro "to go in" (which are used alongside the synthetic synonym entrar "to enter"), are very popular in Italian, in particular in informal speech. The popularity of VPCs may be due to the fact that more meanings can be expressed with the VPCs than with the synthetic forms: there are no synthetic alternatives, for example, for andare appresso/ dietro "to go behind' and andare lontano "to go far" (Iacobini \& Masini, 2006, p. 168). In addition, many of the prefixes found in alternative, synthetic constructions 
are no longer productive. The authors strongly argue against what they call "the Germanic Hypothesis" and claim this is a language-internal development, although it appears to be the case that the phenomenon is particularly popular in dialects in the North. Iacobini \& Masini admit that in Alpine dialects the phenomenon may have been "strengthened by contact with modern German" (p. 165) but insist it is a language-internal development. Unfortunately, the authors do not provide any quantitative evidence for their case, even though a detailed comparison of different corpora could provide further evidence in favour (or against) this claim. The development itself is interesting because the VPCs represent a departure from the perspective of the typology proposed by Talmy $(1985 ; 2000)$ and Slobin (2004), according to which Romance languages belong to the verb-framed category, in that Path is expressed in the verb, whereas Germanic languages tend to be satellite-framed, in that Path is expressed in a satellite that is linked to the verb. In Italian VPCs Path is expressed in a satellite. As Beavers, Levin \& Shiau Wei Tham (2010) have pointed out, in most languages, including English, both Satellite-framed and Verb-framed patterns are available, although one is often used more widely used than the other.

Kramer (1981, p. 130) notes that fixed combinations of verbs with locative adverbs are very frequent in a range of Romance varieties that are close to the Germanic/Romance language border. Kramer and other researchers, including Gsell (1982), Jaberg (1939), Meyer-Lübke (1899, §482) and Rohlfs (1983) assume that language contact with Germanic languages explains the frequency of these constructions in Romance varieties, but unfortunately they do not provide quantitative evidence to corroborate this claim. Dufresne et al. (2003, p.34) and Vincent (1999) dispute the Germanic origin of these constructions, and claim that both prefixation and particles are of Indo-European origin. In Old French aspectual or locative prefixes were highly productive, but this is no longer the case in modern French (Dufresne et al., 2003; Foulet, 1946; Kopecka, 2006). Particles such as sus "up" or jus 
"down" could be used to modify the meaning of a verb in Old French, but structures such as descendre jus/aval "descend downwards" and monter sus/amont "climb upwards" have disappeared as well. According to Foulet (1946, p. 60) it is in particular in redundant constructions such as the two last examples that contact with Germanic varieties can be assumed, which is interesting if one believes with Trudgill (2004) that increased redundancy can be one of the effects of long-term bilingualism. However, as we have seen in section 3, the grammatical collocations under study here are not always or not entirely redundant (e.g. tomber en bas).

In modern French, just like in Italian, verbal prefixes which originate in Latin or Greek can encode Path: in ac-courir "to run to" and s'é-couler "to flow out", for example, the prefix adds the notion of Path to the verb root (Kopecka, 2006, p. 89), but these forms are lexicalised and in many cases not very transparent. It is also possible to use a deictic verb such as aller in combination with a preposition such as hors "out" as in elle va hors de la maison "she goes out of the house" or in combination with an an adverb such as dehors "out", as in elle va (en/au) dehors "she goes out(side)", but the Path verb sortir "to leave", as in elle sort (de la maison) "she leaves (the house)" is used much more frequently for these purposes. A quick search on the French webcorpus of Sketchengine (over 126 million words) shows that combinations of aller + dehors get only 43 hits, but sortir gets 39,590 hits ${ }^{\mathrm{vi}}$. This confirms the results of Hickmann (2006, p. 296) who found that French adults prefer to encode Path in the verb and French children learn the typical ways of expressing motion very quickly from the age of three onwards. French children rarely use satellites to express Path although there are some differences between adults and children with particular items (Hickmann \& Hendriks, 2006, p. 122). British learners of French as a second language, on the other hand, regularly make use of deictic verbs combined with prepositions or path satellites as a means to express motion, possibly because they transfer L1 patterns into 
French, or because these constructions are somehow perceived to be simpler or more transparent than path verbs. Schlyter (1984) and Harley \& King (1989) were the first to show that learners with a Swedish or an Anglophone background overuse venir "to come" and aller "to go" in comparison with native speakers of French who prefer to use verbs which conflate Motion and Path, such as sortir "go out" or entrer "go in". Similar overuses of deictic motion verbs were found among British learners of French (Treffers-Daller \& Tidball in prep.)

Less is known about contact-induced change in grammatical collocations among bilinguals who use a verb-framed and a satellite-framed language. The studies of the particle back in different varieties of Canadian French are particularly relevant in this context. King (2000; 2008) found that in different varieties of Canadian French the English particle back can be used with French verbs (including but not limited to verbs of motion) to produce structures such as venir back "return". Some cases are redundant in that the prefix re- is combined with the English particle, as in revenir back "to come back". In some varieties of French as spoken in Canada back can also be prefixed to the verb as (22).

(22) Il m'a back frappé (Young, 2002; cited in King, 2008, p. 159).

'He hit me back.'

In addition, back can also express meanings it does not have in the source language, as in (23) where it expresses the notion of "again".

(23) Je vous dirai pas back (Roy, 1979, p. 165; in King, 2008, p. 144).

'I won't tell you again'

These two possibilities which do not occur in English illustrate the process of nativisation of borrowings (Mougeon, Brent, Bélanger, \& Cicocki, 1980). According to Mougeon (pc) the 
differences in the usage of back in Canadian French are linked to differences in normative pressures. In communities with prolonged contact with English and low normative pressure, more advanced usages of back are found. In Ontario French, where normative pressures are relatively high, donner back "give back" is possible (see Canale, Mougeon, Bélanger, \& Main, 1977) but back donner is not and the use of back to mean "again" is unattested. In Quebec French, on the other hand, where contact with English is weaker, and normative pressures higher than in Ontario French, back has not entered the morphosyntax of French, nor have de retour or en arrière adopted the meaning "back" (see also Thomason \& Kaufman, 1988, for the influence of intensity of contact on the outcome of language contact).

Chevalier \& Long (2005) show that the importation of particles is not limited to back: six other English-origin particles can be used in French as spoken by adolescent speakers of the Southeast of Canada, namely: out, up, off, on, in and around. In the Acadian French variety which is often referred to as Chiac verb-particle constructions most often consist of an English verb and an English particle, as in (14a), which was discussed in section 3, but combinations with French verbs are also attested: aller on "to go on", (re)garder around "to look around", mettre on "to put on" and sortir out "to go out".

The differences between the Canadian data and the Brussels data are clear: In the Canadian examples English language material is imported into French, and they can thus be seen as examples of MATTER REPLICATION (Matras \& Sakel, 2007). In Brussels French, by contrast, the construction aller de retour "go back" is possible (Baetens Beardsmore (1971, p. 263), but a combination of a French verb with a Dutch particle such as in aller terug "to go back" is not attested ${ }^{\text {vii }}$. In Brussels no material from Dutch but only a pattern is reproduced, so that the process in Brussels is best seen as PATTERn REPLICATION (Matras \& Sakel, 2004). The fact that the Germanic variety is the dominant one in Canada, whereas in Brussels the 
Romance variety is dominant, may in part explain the differences between the outcome of language contact between these two situations (see also Treffers-Daller, 1999).

According to Tremblay (2005, p. 263) in some varieties of French (for example Quebec French) grammatical collocations can be found which consist of a French verb and a French preposition/adverb, such as monter en haut "to go up", descendre en bas "to go down", se lever debout "to get up", mettre bas "to put down" and jeter bas "to throw down". Interestingly, some of the prepositions mentioned here are redundant, and the constructions resemble those found in Brussels French and those mentioned by Gsell (1982), Jaberg (1939) and Kramer (1981). These authors only give examples of combinations of Romance particles with Romance verbs (pattern replication) along the Romance/Germanic language border, but do not bring up any cases of the importation of Germanic particles (matter replication) into the Romance languages. In most of the contact situations under study the Romance language is the dominant variety, which may explain why the results are similar to what we find in Brussels, but different from those in Canada, where matter replication is found too, at least in some varieties. Normative pressures may well play a role too in the frequency with which matter and pattern replication is found in the other bilingual communities, but this is beyond the scope of the current paper.

\section{Method}

The data studied here come from a variety of sources. In order to maximise the comparability of the data across groups of informants, a story telling task was used to elicit semispontaneous data. The frog story Frog where are you? (Mercer Mayer, 1969) was chosen for this purpose, because the story forms a good source of information for the description of 
motion, and many collocations under study here involve motion verbs. The story has also been used by a wide range of researchers in the field of L1 and L2 acquisition. The data from Dutch-French bilinguals $(\mathrm{N}=25)$ were collected in 2006 in Anderlecht, one of the nineteen municipalities of the Brussels Region, situated in the South West of the agglomeration. Among these informants, sixteen can be classified as balanced bilinguals and nine as Dutchdominant (Treffers-Daller in press). The informants' mean age is 62, they had lived all or most of their life in the Brussels Region, and belong to the so-called traditional bilinguals (Janssens, 2001, p. 92): they speak the two languages of the Brussels Region, that is (the regional varieties of) French and Dutch. ${ }^{\text {vii }}$ The informants from Anderlecht also told another frog story (Frog goes to dinner) in the local variety of Dutch, Brussels Dutch, which made it possible to compare the bilinguals' use of some collocations in both languages. The same story could not be used for elicitation in both languages, as this might have triggered unwanted translation effects.

The Brussels data are compared with frog stories from native speakers of French from Paris ( $\mathrm{N}=27$, mean age 21), collected in the same year, and with frog stories from eighteenyear-old Flemish L2-learners of French from the city of Aalst in Flanders $(\mathrm{N}=25)$, who had had six years of French tuition in secondary school prior to data collection. The data were collected and transcribed in CHAT by Laurence Mettewie and Alex Housen, and they are available from the FLLOC database (http://www.flloc.soton.ac.uk/). The other datasets were also formatted in CHAT format and all data were analysed with CLAN (MacWhinney, 2000).

The frog story data are compared with a variety of databases from written and oral sources. Historical data were obtained from Frantext (http://www.frantext.fr/). Beeching's corpus of spoken French (http://www.uwe.ac.uk/hlss/llas/iclru/index.shtml) of about 155000 words as well as the Sketchengine database (http://www.sketchengine.co.uk/) of 126850281 words were used as the sources of information on spontaneous spoken and written data from 
varieties of French that are less likely to have undergone influence from Germanic varieties. These two sources are also used to check whether the frequency of the structures under study in the narratives from Paris is comparable to that in French data from other spoken and written sources, as a low frequency of these structures in the Paris control corpus could be accidental. Finally, a subset of data from Namur and Liège from the Chalons subcorpus of the VALIBEL database (http://www.uclouvain.be/valibel.html) formed the key source on Belgian varieties of French outside Brussels. This subcorpus contains 472018 words. Finally, I have used the Corpus Gesproken Nederlands (Corpus Spoken Dutch) of about 9000000 words (http://www.inl.nl/nl/corpora/corpus-gesproken-nederlands-(cgn)) for the occurrence of the Dutch translation equivalents of the structures under study (e.g. naar beneden vallen and neervallen "to fall down").

From the prepositions/adverbs whose use is discussed in Baetens Beardsmore (1971) I selected those which occurred more than once in the frog stories from Brussels (see Table $2)^{\mathrm{ix}}$. Two of these constructions (courir après "run after" and crier après "call for") are attested in the Petit Robert and the dictionary of the Trésor de la Langue Française Informatisé $^{\mathrm{x}}$ (TLFI) but they were not used at all by the speakers of metropolitan French who told the frog stories. In order to find out to what extent their usage differs in Brussels French and metropolitan French, courir après and crier après were kept in the analysis. In all cases, I carefully checked whether the examples found were indeed the intended collocations and not, for example, verbs followed by temporal adjuncts such as après deux heures "after two hours" or constructions such as those in where regarder après does not mean "to seek" but literally "look behind": thus it does not form a collocation with the verb, but represent a directional adjunct which does not change the meaning of the verb. In (24), the object of the search is not the tree but the frog: thus the little boy is not looking for the tree but behind the tree. Cases such as these were excluded from the calculations. 
A corpus-linguistic approach to transfer

(24) Et il va regarder après l'arbre (speaker 26, learner corpus Housen)

'And he goes looking behind the tree.'

The search strings were formulated in such a way that all the different inflected forms of the verb were included in the searches in all corpora. As other words can sometimes occur between the two parts of grammatical collocations, as in Ils cherchent tous après $X$ "they all look for X", a maximum space of five words was allowed between the verb and the preposition/adverb. Searches in the Dutch corpora are complicated because different word orders are used in the main and the subordinate clause, namely verb+preposition and preposition+verb, and the two parts of the collocation may be written together or written separately depending on the construction. Therefore both word orders, for example naar beneden vallen and vallen naar beneden, were searched in the corpus as well as collocations that were written together as in neervallen or written separately, such as vallen neer. A maximum of five words was allowed between the verb and the preposition/adverb, as for the French corpora. 
A corpus-linguistic approach to transfer

Table 2. Overview of the collocations under study

\begin{tabular}{|l|l|l|}
\hline Collocations with après "after" & $\begin{array}{l}\text { Collocations with (en) } \\
(\text { de)hors (de) / hors de } \\
\text { "out(of)" }\end{array}$ & "down" \\
\hline appeler après "call for" & sortir hors "leave" & tomber en bas "fall down" \\
\hline chercher après "look for" & tomber hors "fall out" & \\
\hline crier après "call for" & & \\
\hline courir après "run after" & & \\
\hline regarder après "look for" & & \\
\hline
\end{tabular}

As it was important to find out not only how many times informants used the different collocations, but also how many times informants could have used a collocation but preferred a bare verb (for example chercher instead of chercher après), I also counted in all transcripts how frequently the different verbs were used without the prepositions/adverbs under study. Subsequently I calculated the relative frequency of the collocations for each informant in relation to the total number of tokens of the same verb. In those cases where more than 100 tokens of a particular structure were found, only the first hundred were scrutinized to establish whether they were the intended collocations, and not tokens of temporal PPs or other structures that needed to be excluded ${ }^{\mathrm{xi}}$. If needed further context was obtained to determine the function of the preposition/adverb in a particular example. The total number of collocations per 100 tokens for all verbs under study was then calculated as follows: the total number of collocations in the Brussels frog story set (41) was divided by the total number of verbs (378). The outcome was multiplied by 100, which leads to a result of 10.85 (see Table 4). 


\section{Results}

\subsection{Intragroup homogeneity and degree of contact with Dutch}

The collocations are widely used by the bilinguals from Brussels, as nineteen of the 25 informants in this group use these structures, whereas only two of the 27 informants from Paris and only one of the 25 informants from Flanders use the collocations under study. The constructions are indeed very rare among the latter two groups, but much more frequent among the group from Brussels (see also Table 3). The standard deviations reported in Table 3 are somewhat higher in the Brussels group than among the two other groups, which indicates there is more variation within the Brussels group than within the two other groups.

In order to find out whether degree of contact with Dutch could explain the frequency of usage of the collocations, I operationalised degree of contact with the source language (Dutch) by dividing the group into those who attended a Dutch-speaking primary school (15 informants) and those who went to a French-speaking primary school (6 informants). The remaining four informants claimed that both languages were used in class or did not provide any information regarding the languages spoken at school, so these informants were excluded from this analysis. The frequency with which the informants in the bilingual group use the collocations may indeed be related to the languages spoken in school, as among those who went to a Dutch-speaking school the relative frequency of the collocations is 12.9 , whereas among those who attended French-speaking schools the relative frequency is 6.6. The differences are not significant, but represent a trend ( $\mathrm{t}=1.39 ; \mathrm{df}=19, \mathrm{p}=.092$ (one-tailed)), which indicates that, if further data could be collected, this factor (i.e. the language of schooling) would probably turn out to be a predictor of the use of the collocations under study. 


\subsection{Intergroup heterogeneity}

In this section I will compare the data from Brussels French with data from related varieties which have or have not undergone influence from a Germanic variety. In the first section a comparison will be made between the frog stories from Brussels, Flanders and Paris; in the second section the Brussels data are compared with evidence from a large corpus of spontaneous French that has not been influenced by Germanic varieties and in the third section alternative explanations based on internal developments are explored.

6.2.1 A comparison between the frog stories of the three groups

Table 3 gives the mean frequency of the collocations per group and demonstrates that the collocations are far more frequent among the bilingual group from Brussels than among the two other groups, and these differences are significant (ANOVA, $F(2,72)=24.39$, p<.001). A post-hoc analysis reveals that the Brussels group is significantly different from the two other groups, but the differences between the Paris group and the group from Flanders are not large enough to become significant. ${ }^{\text {ii }}$ 
Table 3. The frequency of the collocations under study in the frog stories of the informants from Brussels, Paris and Flanders

\begin{tabular}{|l|l|}
\hline & $\begin{array}{l}\text { Collocations of Verb+prepositions } \\
\text { Mean (SD) }\end{array}$ \\
\hline Brussels & $1.92(1.8)$ \\
\hline Paris & $0.13(0.3)$ \\
\hline L2 learners from & $0.04(0.2)$ \\
\hline Flanders & \\
\hline
\end{tabular}

A more detailed picture of the frequency of different constructions can be found in Table 4 . Three of the collocations, chercher après, crier après and tomber en bas are relatively frequent in the Brussels corpus. All others occur less than ten times. A calculation of the relative frequency of all collocations (i.e. frequency per hundred tokens of the verb) shows that they occur on average 10.85 times per hundred tokens. In the L2 learner corpus and the Paris corpus almost no collocations are found ${ }^{\text {xiii }}$ : there is only one token of tomber en dehors in the learners' corpus and the informants from Paris produce one token each of tomber en bas and tomber hors de.

As two reviewers point out, speakers could also have opted to use the slightly more formal, synthetic alternative, namely poursuivre "to chase (after)" instead of courir après, and appeler "to call" instead of crier après. ${ }^{\text {xiv }}$ As it turns out, all groups do indeed use poursuivre, but it is clearly favourite among the Paris group (26); it is least used by the Flemish L2 learners (2), and the Brussels group occupies the middle position with nine tokens. The Brusselers use crier après (16), but they also use appeler frequently (25). The Paris group and the learner group do not use crier après but instead use appeler 52 and 22 
A corpus-linguistic approach to transfer

times respectively. This analysis reinforces the conclusions drawn on the basis of Table 3, namely that the option to use a collocation is most often chosen among the Brussels informants. For the other collocations there are no obvious alternatives except using the verb without the preposition/adverb.

Table 4 Frequency of each collocation and their corresponding verbs in the Brussels French frog story data

\begin{tabular}{|l|l|l|l|}
\hline & $\begin{array}{l}\text { Frequency of } \\
\text { collocations of }\end{array}$ & Tokens of each verb & Frequency \\
& verbs+prepositions & & of \\
& $(\mathrm{N})$ & & tokens of each verb \\
\hline appeler (après) & 2 & 26 & 7.69 \\
\hline chercher (après) & 10 & 61 & 16.39 \\
\hline courir (après) & 3 & 22 & 13.64 \\
\hline crier (après) & 13 & 36 & 36.11 \\
\hline regarder (après) & 1 & 66 & 1.52 \\
\hline sortir (en de)hors (de) & 2 & 68 & 2.94 \\
\hline tomber (en bas (de) or & $10(9+1)$ & 99 & 10.10 \\
\hline en dehors (de) & & 378 & \\
\hline total & 41 & & \\
\hline
\end{tabular}

\subsubsection{Comparison with data from Belgian French and Canadian French}

In this section the focus is on the frequency of the patterns in a corpus of Belgian French from Wallonia, which forms part of the VALIBEL corpus. As explained in section 1, I assume the collocations will be less frequent in these varieties, because the speakers are less 
influenced by Dutch and thus transfer from this language is less likely. The results in Table 5 show that only two of the collocations under study were found in the VALIBEL corpus: chercher après and sortir en dehors, and they occur ten times less often than in Brussels French $^{\mathrm{xv}}$ : only 0.8 times in one hundred tokens of the verbs. It will be interesting to compare these results with French data from France, as even less influence from Germanic varieties is expected there. This will be dealt with in section 6.3.

Table 5. Frequency of the collocations in the VALIBEL corpus of Belgian French

\begin{tabular}{|l|l|l|l|}
\hline & $\begin{array}{l}\text { Frequency of } \\
\text { collocations of }\end{array}$ & Tokens of each verb & Frequency \\
& prepositions (N) & & collocations per 100 \\
& tokens of the verb \\
\hline Chercher (après) & 3 & 101 & 2.97 \\
\hline Courir (après) & 0 & 8 & 0 \\
\hline Crier (après) & 0 & 14 & 0 \\
\hline Regarder (après) & 0 & 170 & 0 \\
\hline Sortir (en dehors de) & 2 & 266 & 0.75 \\
\hline Tomber (en bas or en & 0 & 65 & 0 \\
\hline dehors) & & 624 & \\
\hline total & 5 & & 0.80 \\
\hline
\end{tabular}

The constructions found are very similar to those found in Brussels. In (25a) we find chercher used with the adverb après and in (25b) the same verb is followed by a prepositional phrase headed by après. 
A corpus-linguistic approach to transfer

(25a) La petite soeur cherchait après (i.e. le grand monstre)

'The little sister looked for (it = the big monster).' (corpus VALIBEL, speaker ilrDC5)

(25b) Je dois chercher après mes mots

'I have to look for my words.' (corpus VALIBEL,speaker ilrDG1)

In (26) the speaker use sortir with a prepositional adjunct in en dehors de.

(26) On ne sort jamais en dehors de Ciney

'We never go out outside Ciney.' (corpus VALIBEL, speaker ilrCS1)

A brief comparison with data from Mougeon \& Beniak's (1991) corpus of Ontario French (Mougeon et al., 2005) is interesting at this point, as two of the verbs under study here, regarder and chercher, occur with adverbs or prepositions in Ontario French too. The preposition used by French Canadians is pour, the translation equivalent of English for, as shown in (27) and (28), and not après "after", which is the translation equivalent of Dutch na/naar/achter.

(27) Inspector Clouseau il regardait pour un homme.

"Inspector Clouseau he was looking for a man.” (Mougeon et al., 2005, p. 105)

(28) Mais là je vas chercher pour de l'emploi.

"But you know I am going to look for a job."

Thus, in Brussels French, Belgian French and Ontario French a preposition is added to these verbs, but the choice of the preposition differs in these varieties as it based on the translation equivalent in the contact language. In Brussels French and in the Valibel corpus, regarder 
pour and chercher pour are not attested, and no mention is made of regarder après or chercher après in Ontario French. After completing a detailed comparison of the use of these verbs in a variety of data from speakers, Mougeon and colleagues conclude that the source of the innovations in Ontario French is likely to be English, because degree of contact with the source language English explains the frequency of occurrence of these forms (Mougeon et al., 2005). As we have seen in section 6.1, there is not yet enough evidence to draw conclusions about this issue for Brussels French. Mougeon et al. (2005, p. 108) also note that the use of the verb regarder with the preposition pour, which together encode the meaning "to seek" (a calque from "to look for"), represents a more in-depth form of contact-induced change than the use of chercher pour because the former entails not only the insertion of pour, but also the substitution of regarder for chercher, whereas the latter only involves the addition of a preposition.

In (29) the regarder après can be translated as "to look for" or "to seek" but not as "to look at": this would only be possible if the frog was in the jar, which is not the case in the picture. Thus, in this case the verb regarder has probably indeed assumed the meaning of chercher, but this transfer of meaning cannot be explained as contact-induced, because the Brussels Dutch translation equivalent zien or bezien "to look at" does not mean "to seek"xvi .

(29) Le petit garçon regarde le chien, qui regarde dans le bocal pour la grenouille après la grenouille (corpus Brussels, JTD, speaker 11)

'The little boy watches the dog, who looks into the jar for the frog for the frog.'

This example is also interesting because the speaker corrects herself, in that she first uses pour and then après, which clearly demonstrates the difference between Canadian and Brussels French. 
Studies of L2 acquisition provide important information about the link between learners' L1 and the use of these two collocations in French. According to Desmet, Klein \& Lamiroy (2004, p. 113) Dutch learners of French often add the preposition après after chercher, whereas anglophone learners often add pour to this verb (Holmes, 1977; in Lumsden, 1999, p. 132). Learners of French with Dutch and Anglophone backgrounds thus make different errors in their uses of the verb chercher, and these errors are linked to their L1.

Finally, Mougeon $(\mathrm{pc})$ notes that courir après occurs sixteen times in the Ontario French corpus of one million words, and the more formal equivalent poursuivre occurs twelve times. Further evidence regarding the role of language contact in the occurrence of this form and the other collocations will be obtained through the analysis of data that have not been influenced by a Germanic language, which will be done in the next section.

\subsection{Alternative explanations: evidence for internal developments?}

In this section we will first look at two corpora from modern French: Beeching's corpus of spoken French from France and the Sketchengine corpus (section 6.3.1) and then we will look at the historical development of these collocations in data from five centuries in the Frantext corpus (section 6.3.2).

\subsubsection{The collocations in modern French}

There is some evidence that these collocations occur in varieties of French that have not been influenced by Germanic varieties. In his study of popular French, Bauche (1920, p. 148) notes that prepositions can be placed at the end of a sentence, with or without complement, 
A corpus-linguistic approach to transfer

"un peu à la façon de la particule séparable allemande" as in (30), which corresponds to the structures found in Brussels.

(30) Je lui ai couru après (Bauche, 1920 , p. 149)

I him ran after

'I ran after him.'

Gadet (2007) does not mention après, but notes that the use of sans "without" and dessus “on" as prépositions orphelines or stranded prepositions, as in (31) and (32), is not limited to Belgian French. She therefore doubts that language contact is to be invoked in explaining the occurrence of such prepositions.

(31) Elle a un nounours qu'elle peut pas dormir sans (Gadet, 2007, p. 24)

'She has a teddybear that she cannot sleep without.'

(32) Il passe son temps à me copier dessus (Gadet, 2007, p. 24)

He spends his time to me copying on.

'He continuously copies me.'

Interestingly, Bauche (1920, p. 149) also mentions the use of après with "some other verbs", namely monter après un mur "to climb onto a wall", demander après qn "to ask for someone", chercher après qn "to look for someone" and attendre après qn ou qc "to wait for someone or something". These collocations are still found at the end of the twentieth century. In his study of colloquial French Ball (2000, p. 122) mentions that stranding of the preposition is possible with for example crier après "to shout at", aboyer après "to bark at" 
and attendre après "to wait for" and demander après "to ask for someone" and notes that the last two usages are colloquial.

According to Baetens Beardsmore (1971), these verbs are used in this way in Brussels French too, but there is a wider range of verbs that can be used with après or pour in Brussels French, namely e.g. voir après "to look after", sentir après "to feel for", goûter après "to taste after/like", parier pour "to bet on", soigner pour "to take care of", etc. For many of these verbs translation equivalents exist in Dutch, which is why transfer from Dutch is often assumed to be the source of these constructions in Brussels French.

It is not possible, however, to decide whether transfer from Dutch plays a role in these structures if one considers isolated examples only. It is information regarding the frequency of these collocations in different speech communities that can shed new light on the issue, as in bilingual communities some variants may be used more frequently than in others because they correspond to variants found in the contact language. If this can be shown to be the case in Brussels, this will provide evidence for covert transfer (Mougeon et al., 2005).

Therefore I will now compare the frequency of collocations in the frog story data from Brussels with their frequency in corpora of spontaneous metropolitan French. First of all I searched the collocations in Beeching's corpus of French as spoken in France (155 000 words) and then in the French corpus of Sketchengine (126 850281 words $)^{\text {xvii }}$. A frequency analysis of these collocations in popular French could also have provided highly interesting information, but to the best of my knowledge, such a corpus is not currently available. In Beeching's corpus only one collocation with après was found, namely courir après, shown in $(33)^{\text {xviii }}$. As we have seen above, this is one of the two collocations which are also attested in the Trésor de la langue française informatisé (TLFI).

(33) Je peux pas courir après (corpus Beeching, Speaker B, line 278)

'I cannot run after (him/her).' 
The prepositional phrase après ça in (34) is not linked to the verb chercher, but to the following clause il se disait "he said to himself", although there are no pauses between the verb chercher and après ça or between the PP and the following clause. The PP does not refer to an object the speaker is looking for, but refers to an earlier event. Thus, après ça is a temporal PP and not part of a collocation with chercher (Beeching, p.c.). None of the other collocations were found in this corpus.

(34) Alors il cherchait après ça il se disait si je me mets, je vais me jeter dans un virage avec ma mobylette (corpus Beeching, speaker B, line 664).

'Then he searched, after that he said to himself, if I put myself, I will throw myself off my motorbike in a bend in the road.'

The results from Sketchengine confirm the findings based on Beeching's corpus: the collocations under study are very rare in modern spontaneous French. Table 6 presents the frequency of each of the collocations in the Sketchengine corpus, as well as the frequency of the same verbs without the preposition/adverb, and the relative frequency of the collocations, that is their frequency per hundred tokens of each verb. These results show that among the collocations studied here courir après is the most frequent one in this corpus, but the other collocations do not occur more than once in a hundred tokens of the verb. On average, the collocations under study occur only 0.37 times per one hundred verbs in the Sketchengine corpus, which is less than in the Belgian French corpus (0.8) and much less than in the Brussels French frog story corpus (10.85). 
Table 6 Frequency of different collocations and their corresponding verbs in the French corpus of Sketchengine.

\begin{tabular}{|l|l|l|l|}
\hline & Total number of & Frequency of the & Collocation per \\
& collocations of verbs & verb without this & 100 tokens of \\
prepositions/adverbs & preposition/adverb & each verb \\
\hline appeler (après) & 0 & 41,420 & 0 \\
\hline chercher (après) & 5 & 37,477 & 0.013 \\
\hline courir (après) & 560 & 11,866 & 4.72 \\
\hline crier (après) & 40 & 9,111 & 0.44 \\
\hline regarder (après) & 2 & 36,432 & 0.006 \\
\hline sortir (hors de or en & $118(50+68)$ & 39,590 & 0.31 \\
\hline dehors) & & 29,121 & \\
\hline tomber (en bas or & $26(19+7)$ & & 0.09 \\
\hline en dehors) & & 205,017 & \\
\hline total & & & \\
\hline
\end{tabular}

Although the analysis of the data from Beeching's corpus and Sketchengine corpus clearly shows that the collocations under study are rare in modern spoken French, it is of course possible that they were more frequent in previous centuries. Thus, the constructions in Brussels French could be archaisms which have survived in this variety. As is well-known, regional varieties of French, including those spoken in Belgium and Canada, are often marked by archaisms (Francard \& Latin, 1995), but to my knowledge the structures mentioned here have not thus far been considered to fall in this category. Therefore I have scrutinised historical data from the previous five centuries to find out whether the 
collocations under study here were more frequent in the past. Of course comparing oral data with written data is problematic, but for obvious reasons, we can only get access to written historical data.

\subsubsection{Historical development of the patterns}

The results in Figure 1 show that the collocations were indeed used in the previous centuries, and there is a gradual decline in their use from the sixteenth century onwards. Only the development of courir après differs from the other collocations in that it becomes more frequent in the $18^{\text {th }}$ century, after which the decline sets in. It is still relatively frequent in the $20^{\text {th }}$ century in comparison with the other collocations. There are no examples at all of appeler après, and very few of regarder après or chercher après ${ }^{x i x}$. As the number of collocations does not exceed 3.5 per hundred tokens of each verb, it is clear they are not very frequent in any of the centuries studied here, and there is a clear downwards trend in their use, which is even clearer in Figure 2, which represents the averages for all forms. The decline presented here stands in marked contrast to the development in Italian, where such collocations are increasingly common (see section 4). 
Figure 1. Frequency of the collocations per hundred tokens of each verb from the $16^{\text {th }}$ to the $20^{\text {th }}$ century (based on Frantext).

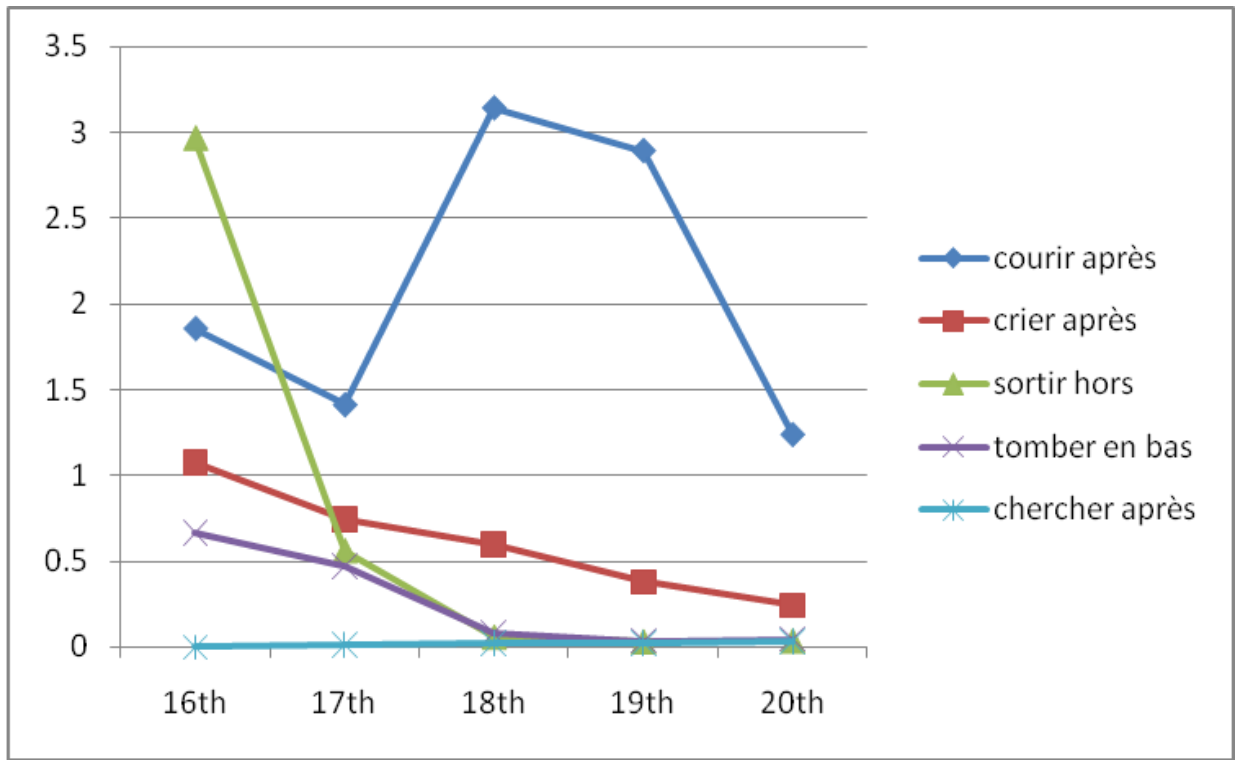

In the $16^{\text {th }}$ century we find examples of courir après, crier après, sortir (de)hors and tomber en bas/à bas, and they are illustrated in (35) - (38).

(35) Mais Gargantua courut après et l'empoigna par le collet (Anonyme 1534. Les chroniques admirables, p. 278)

'But Gargantua ran after (him = Gallimassue) and grabbed him by the collar.'

(36) J'ay une coustume de crier la nuict après mes oyseaulx. (Des Périers, Bonaventure. Les Nouvelles récréations et joyeux devis de feu 1, p. 463)

'I have the habit of shouting at night at my birds.' 
A corpus-linguistic approach to transfer

(37) ... et qu'on les voulloit faire sortir hors de la chambre. (Vigneulles, Philippe de. 1515, Les cent nouvelles nouvelles, p. 244)

'And that they wanted to make them leave the room.'

(38) Quand elles (= les étoiles) esclairent et qu'elles tombent en bas, à terre... (PalmaCayet, Pierre-Victoire, 1598. L’Histoire prodigieuse du Docteur Fauste,p. 140.

'When the stars light up and they fall down, to earth.'

In (39) we see the earliest example of regarder après, as found among 6698 tokens of the verb regarder in the $17^{\text {th }}$ century subcorpus of Frantext, which consists of 21 million words. It is the only time we find this collocation in this century. In this scene, Alidor warns his friend Cléandre that the woman they are both in love with, Angélique, may discover that they have exchanged roles. As she might scream when she discovers she has been deceived, Cléandre is told to watch out for her cries.

(39) Regarde après ses cris si tu serois le maître (Corneille, P. (1682), La place royale, p. 274, Acte IV, scene 2). ${ }^{\mathrm{xx}}$

'Watch out for her cries if you want to be the master.'

The earliest example of chercher après is found in the $17^{\text {th }}$ century corpus too (see 40). There are 7219 tokens of chercher in this corpus, but only one of these is a collocation with après.

(40) Et c'étoit vraisemblablement la disposition de ceux qui cherchoient après Lazare pour le mettre à mort. (Abbadie, Jacques, 1684. Traîté de la vérité de la religion chrétienne. Vol 2, p. 156.) 
A corpus-linguistic approach to transfer

'And it was probably the mood of those who were looking for Lazarus, seeking to kill him.'

The historical data clearly show that the collocations studied here were used from the $16^{\text {th }}$ century onwards, even though they are extremely rare, especially in the more recent past, and never exceed one in a hundred tokens of the verb. Although this means that that there is at least some evidence that the collocations in Brussels French can be explained as archaisms, they are much more frequent in Brussels French, where we find 10.85 collocations per hundred verbs, than in the historical data from the previous five centuries. It is therefore clear that historical explanations on their own are not sufficient to explain the high frequency of the collocations in Brussels French.

Figure 2. Average frequency of five collocations from the $16^{\text {th }}$ to the $20^{\text {th }}$ century (per 100 tokens of the verbs).

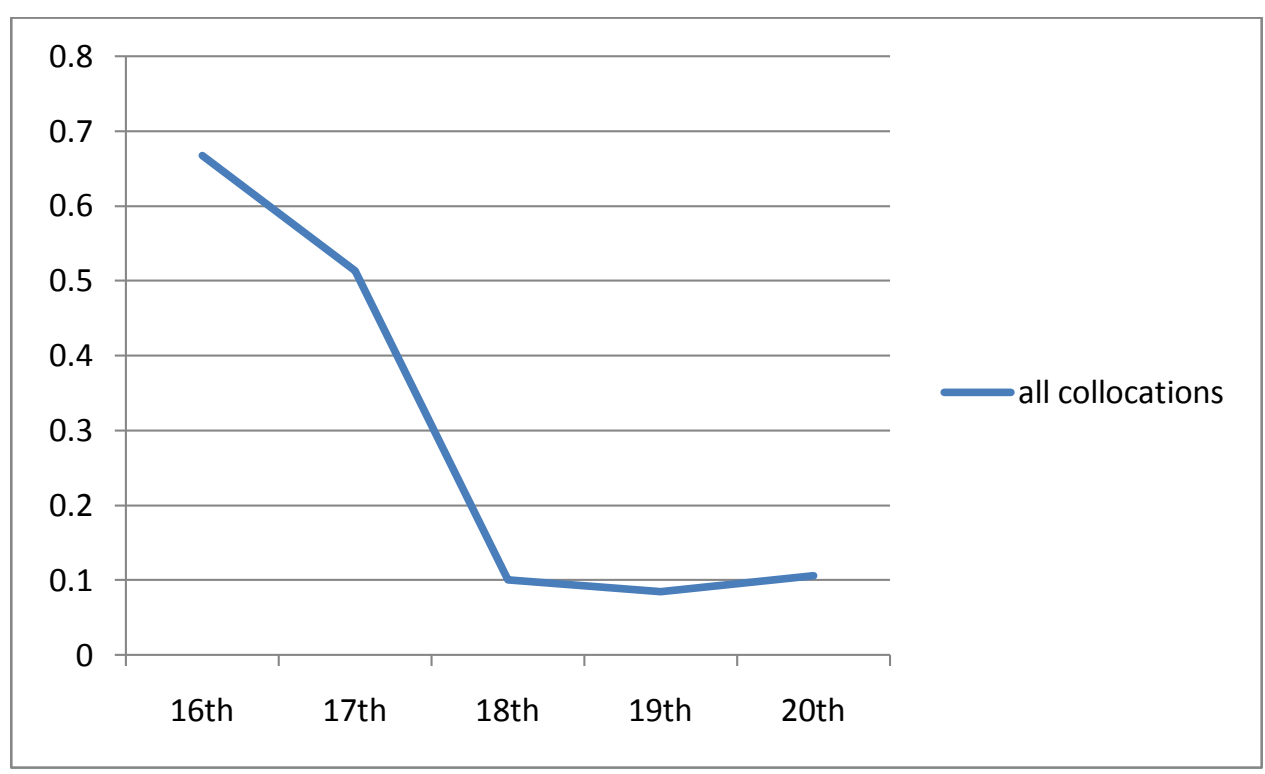


A corpus-linguistic approach to transfer

\subsection{Crosslinguistic performance congruity}

In this section we will explore the existence of crosslinguistic performance congruity in Dutch and French as spoken by bilinguals in Brussels. In other words, we want to know whether there are similarities between the bilinguals' use of collocations in the recipient language (French) and their use of collocations in the source language (Dutch). While a detailed comparison of L1 and L2 performance of the same speakers is not possible at this point, as the speakers told different frog stories in the two languages, to avoid unwanted translation effects, Dutch collocations such as zoeken naar/achter "to look for", as in (41), and roepen naar "to call for", as in (42), which are translation equivalents of the Brussels French collocations chercher après and crier après are attested in the data.

(41) en de schildpadde die zit achter daan kikker aan 't zoeken (corpus JTD,

informant 3)

And the tortoise it sits behind that frog on the looking

'And the tortoise is looking for the frog.'

(42) En hij roept naar die patron. (corpus JTD, informant 24)

'And he calls for the restaurant owner.'

The Southern Dutch translation equivalent of courir après, achter X lopen "run after $\mathrm{X}$ aan"xxi as in (43) was also found in the data. 
A corpus-linguistic approach to transfer

(43) Ik loop achter daan meneer en ik pak mijn kikvors weer (corpus JTD, informant

'I walk after that gentleman and I take back my frog.'

In the Dutch frog story corpus there were no tokens of the Dutch translation equivalent of tomber en bas, possibly because the story Frog goes to dinner did not provide the right context for this collocation to be used. A search in the Corpus Spoken Dutch demonstrates, however, that naar beneden vallen and neervallen (which both mean "fall down") are common expressions in Dutch. The translation equivalents of the other structures under study are all frequent in this corpus too (see Table 7). In some cases, different translation equivalents were possible, as for example courir après can be translated into Dutch as achter $X$ aanrennen "to run after X" or achter X aanlopen "to walk after X", and there is a wide range translation equivalents for sortir dehors. ${ }^{\text {xxii }}$ The different options were all searched in the Dutch corpus. For the purposes of the current paper it is however important to note that the use of the preposition naar (or achter) is not obligatory with roepen "to call" or zoeken "to search": the verbs can be used with a direct object or a prepositional phrase, as in (naar) iemand/iets zoeken "to search (for) someone/something" and (naar) iemand/iets roepen "to call (for) someone/something"xxiii. As Table 7 below demonstrates, in Dutch the collocations occur 3.5 times per hundred tokens of each verb. Comparing the frequency of the collocations in Dutch to those in French is however problematic, because the translation equivalents of the verbs are unlikely to occur with the same frequency in different languages. However, the fact that these translation equivalents exist and are relatively frequent in spoken Dutch provides additional support for the assumption that the collocations in Brussels French have become a major use pattern under the influence of Dutch. 
A corpus-linguistic approach to transfer

Table 7. Frequency of translation equivalents of French grammatical collocations in the Corpus Spoken Dutch

\begin{tabular}{|l|l|l|l|}
\hline Dutch grammatical collocations & Frequency & Frequency of & Collocation \\
& & verb 100 tokens & of each verb \\
\hline $\begin{array}{l}\text { Naar beneden vallen and neervallen } \\
\text { "fall down" }\end{array}$ & $46(20+26)$ & 4067 & 1.13 \\
\hline Zoeken naar/achter "search for" & $350(326+11)$ & 2272 & 15.40 \\
\hline Roepen naar "call for" & 49 & 1137 & 4.31 \\
\hline Lopen achter X aan "walk behind X" & 25 & 5685 & 0.44 \\
\hline Rennen achter X aan "run after X" & 4 & 298 & 1.34 \\
\hline total & 474 & & 3.52 \\
\hline
\end{tabular}

A final highly interesting illustration of the influence of Dutch in the production of a French collocation can be found in (44), where the speaker uses a hybrid collocation consisting of a combination of the French verb chercher with the Dutch preposition naar "after".

(44) Il cherche il cherche, il cherche naar dans un trou (corpus JTD, speaker 14).

'He looks, he looks, he looks for in a hole.'

A possible explanation for this hybrid collocation can be sought in the speaker's language dominance profile. From an analysis of this speaker's vocabulary (Treffers-Daller in press) 
we know that he is clearly Dutch-dominant in that he obtained a score above the median for Dutch and a score below the median for French on the D measure of vocabulary richness (Malvern, Richards, Chipere \& Durán, 2004). It is fascinating to see the speaker's dominant language being activated exactly at the moment of the production of the collocation. It is probably the dual activation of the two languages which results in him producing a hybrid construction. In this particular case, it seems to me that we are dealing with a dynamic phenomenon which is linked to processing, i.e. interference in Grosjean's terminology, while in the other examples which are found among a wide variety of speakers, the collocations reflect permanent traces of Dutch on French, and are thus best seen as examples of transfer.

\section{Discussion and conclusion}

While transfer has been studied extensively over the past few decades and insights into the role of transfer in SLA and in studies of language variation and change have increased considerably, there is still a great deal of confusion about the nature of transfer and how it is best investigated. The aim of this paper was to provide evidence regarding the claim that Brussels French grammatical collocations which consist of a verb with a preposition or an adverb chercher après "to look for" are the result of transfer from Brussels Dutch, following the methodology proposed by Jarvis (2000), Jarvis \& Pavlenko (2008) and Mougeon, Nadasdi \& Rehner (2005) for identifying transfer. Collocations and verb-particle constructions have been studied widely in the Germanic languages as well as in Italian, but less attention has been paid to their occurrence in French, in which verb-particle constructions are assumed to be much less common. It has been known for a long time, however, that a range of grammatical collocations and some verb-particle constructions can be found in Brussels French and other Romance varieties along the linguistic frontier 
(Baetens Beardsmore, 1971; Kramer, 1981), although evidence for the claim that their use is related to transfer from Dutch or German varieties was never provided.

After a brief review of the key concepts of contact-induced change, transfer and replication, the most important syntactic and semantic properties of the collocations in Brussels French were presented. With the help of Jackendoff's tests to distinguish particles and prepositions, it was established that most of the constructions with après, (en de)hors (de) and en bas (de) that occur in the Brussels French data set under study are not particles, because they fail Jackendoff's movement tests. For this reason, it would be incorrect to consider the constructions in which they are used as verb-particle constructions, and the term "grammatical collocations" (Granger and Paquot, 2008) was chosen instead. A few examples from Baetens Beardsmore (1971) and one example from De Vriendt (2004) could however be considered as VPCs. The Brussels French patterns were shown to differ clearly from Canadian French constructions such as shutter off "to shut off". In the Canadian contact situation English language material has been imported into French, whereas in Brussels French only a pattern has been replicated, but no language material has been transferred into French. It is likely that differences in social pressure and intensity of contact (Thomason \& Kaufman, 1988, p. 46) between the contact languages are responsible for the dissimilar outcomes of language contact in these two language communities. French is the dominant language in Brussels, whereas it is the non-dominant language in many Canadian communities. In particular in those Canadian communities where pressure from English is strong, advanced forms of language contact such as the importation of VPCs from English are found. In Brussels, where French is much less under pressure from the contact language, no VPCs are imported from Dutch, but some VPC patterns are replicated.

In the results section, the focus was on providing the three kinds of evidence needed if one wants to argue a feature is contact-induced: intragroup homogeneity (uniformity of 
behaviour of bilinguals in Brussels with respect to the patterns under study); intergroup homogeneity (differences between the Brussels group and other groups which are or are not in contact with the same source language), and crosslinguistic performance congruity (similarities in the structures produced by bilinguals in their two languages).

The first set of evidence that was investigated consisted of frog stories collected among bilinguals in Brussels. The results revealed that 19 out of 25 informants in this group use these collocations, which demonstrates that the phenomenon is not an isolated incidence and the group behaves in a relatively uniform manner with respect to this feature. In addition, there was a trend for speakers who had been to Dutch schools to produce these collocations more frequently than those who had been to French schools, so that contact with Dutch is probably a factor that can to some extent explain the frequency of occurrence of the phenomena.

A comparison between the French frog stories from Brussels and those produced by a control group from Paris and a control group of L2 learners of French from Flanders confirmed that there are significant differences between the Brusselers and the other two groups in their use of these collocations. In Brussels, collocations were found on average 10.85 times out of a hundred tokens of each verb, while in Paris there were virtually no examples of these constructions. While this in itself would have been enough to demonstrate intergroup heterogeneity, further evidence from other French corpora (spoken data from Wallonia and France, written data from literary sources and from internet sources) was sought to establish whether the absence of these collocations in the data from the control groups was accidental. The VALIBEL corpus of Belgian French contained examples of chercher après and sortir en dehors, but their frequency was much lower than in the Brussels French frog stories ( 0.8 per hundred tokens). Beeching's corpus of modern spoken French and the Sketchengine corpus contained even fewer examples of these constructions $(0.34$ per 
one hundred tokens). The fact that the frequency of the collocations was equally low in such a wide variety of data is remarkable, and strengthens the validity of the analyses presented here.

Alternative internal explanations, in particular the possibility that the patterns in Brussels French are archaisms, were also explored. The analysis of collocations in historical data from the $16^{\text {th }}$ century onwards revealed that most of the collocations under study do occur in historical data, with the exception of appeler après "to call for" which was not found in any of the other sources. The collocations are however extremely infrequent in the historical data or the $20^{\text {th }}$ century Frantext corpus, whilst they are much more frequent in Brussels French. Little evidence was found for qualitative differences between the use of collocations in Brussels French and other varieties, except for some Dutch influence in a number of constructions. Although it is likely that normative pressures have played a role in the demise of these patterns, it is unlikely that internal factors are sufficient to explain these contrasts: An additional, external factor is likely to have played a role.

The most plausible explanation for the facts is that knowledge and use of Dutch has led to an increase in the use of collocations by bilinguals in Brussels, in other words that the structures are the result of covert transfer (Mougeon et al., 2005) or pattern replication (Matras \& Sakel, 2004) from Dutch. In Heine \& Kuteva's (2004) framework the structures can be seen as replications of a grammatical use pattern which existed as a minor use pattern in French and which has become a major use pattern in Brussels French under the influence of Dutch.

A number of facts discussed in this paper point to influence from Dutch as the key factor that can explain the high frequency of the collocations in Brussels French. First of all there is a trend for bilinguals who went to Dutch schools to produce more of these collocations; second, an analysis of Dutch frog stories produced by the same bilinguals from 
Brussels confirmed that the speakers use many Dutch patterns that are translation equivalents of the French collocations, such as zoeken naar "to look for" and roepen naar "to call for". A quantitative analysis of the translation equivalents in the Corpus Spoken Dutch revealed that these are indeed common in spoken Dutch. Third, for one informant from the bilingual group it could be shown that Dutch was activated during language production, because he produced a hybrid collocation which consisted of the French verb chercher and the Dutch preposition naar. Fourth, it is well-known that Dutch learners of French often produce the form chercher après (Desmet et al., 2004), whilst Anglophone learners of French use the forms chercher pour or regarder pour (Mougeon et al., 2005). The most likely explanation for the differences is that they are the result of transfer or pattern replication (Matras \& Sakel, 2004; Heine \& Kuteva, 2005) from the students' first language.

The current paper clearly shows that the rigorous methodology to transfer proposed by Jarvis (2000), Jarvis \& Pavlenko (2008) and Mougeon et al. (2005) can help disentangle the role of internal and external factors in language variation and change. The differences in the frequency of the phenomena across a range of corpora provided the key evidence for the role of transfer from Dutch in the use of these collocations in Brussels French. It would be very interesting to see this approach applied to studies of VPCs in Italian and other languages spoken along the Romance/Germanic language border. Further studies of the frequency of these structures in popular French would also be extremely useful, as it appears that some of the structures under study here do occur in popular French. In addition it would be relevant to study the frequency of these collocations in the speech of monolingual French speakers from Brussels, as this will give us further information about the diffusion of the phenomenon across the speech community of French speakers in Belgium. Factors such as social class and register may also play an interesting role here. These issues will need to be addressed in further studies of this fascinating phenomenon. 
A corpus-linguistic approach to transfer

\section{References}

ABERCROMBIE, D. (1967). Elements of General Phonetics. Edinburgh: Edinburgh University Press.

BAETENS BEARDSMORE, H. (1971). Le français régional de Bruxelles, Université Libre de Bruxelles, Institut de Phonétique, conférences et travaux 3. Bruxelles: Presses Universitaires de Bruxelles.

BALL, R. (2000). Colloquial French grammar. A practical guide. Oxford: Blackwell.

BAUCHE, H. (1920). Le français populaire. Paris : Payot.

BEAVERS, J., LEVIN, B. \& S.W. THAM (2010). The typology of motion expressions revisited. Journal of Linguistics, 46(2), 331-377.

BOOIJ, G. (2002). Separable complex verbs in Dutch: A case of periphrastic word formation. In: Dehé et al. (eds.) Verb-particle explorations (pp. 21-42). Berlin/New York: Mouton de Gruyter.

BOOIJ, G. (2010). Construction morphology. Oxford: Oxford University Press.

CANALE, M., MOUGEON, R., BELANGER, M. \& MAIN, C. (1977). Recherches en dialectologie franco-ontarienne. Working Papers on Bilingualism, 14, 1-20.

CHEVALIER, G. \& LONG, M. (2005). Finder out pour qu'on les frigge pas up, comment c'qui workont out: les verbes à particules en chiac. In P.Brasseur \& A. Falkert (eds.) Français d'Amérique: approches morphosyntaxiques. Actes du colloque international Grammaire comparée des variétés de français d'Amérique (pp. 201-212). Paris: L’Harmattan.

DEHE, N. R. JACKENDOFF, A. MCINTYRE \& S. URBAN (2002). Verb-particle explorations. Berlin/New York: Mouton de Gruyter.

DESMET, P., KLEIN, J.-R. \& LAMIROY, B. (2004). Vous dites ?! Répertoire d'erreurs courantes en français chez les néerlandophones. Leuven/Voorburg: Acco. 
DE VRIENDT, S. (2004). Brussels. Tielt: Lannoo.

DUFRESNE, M., DUPUIS, F. \& Tremblay, M. (2003). Preverbs and particles in Old French. In G.Booij \& J. van Marle (eds.) (2003) Yearbook of morphology (pp. 33-60). Kluwer Academic Press.

FOULET, L.(1946). L’effacement des adverbs de lieu. Romania, 69, 1-79.

FRANCARD, M. \& LATIN, D. (1995). Le régionalisme lexical. Louvain-laNeuve: Duculot.

GADET, F. (2007). La variation sociale en français. Nouvelle édition revue et augmentée. Paris: Ophrys.

GRANGER, S. \& PAQUOT, M. (2008). Disentangling the phraseological web. In S. Granger \& F. Meunier (Eds.), Phraseology. An Interdisciplinary perspective (pp.2750). Amsterdam/Philadelphia: John Benjamins.

GROSJEAN, F. (this volume). An attempt to isolate, and then differentiate, transfer and interference. International Journal of Bilingualism.

GSELL, O. (1982). La rosas dattan ora - les röses da fora - le rose danno fuori: Verbalperiphrasen mit Ortsadverb im Rätoromanischen und im Italienischen. In S. Heinz, \& U. Wandruszka (Eds.), Fakten und Theorien. Festschrift für Helmut Stimm (pp. 71-85). Tübingen: Günter Narr.

HARLEY, B. \& KING, M.-L. (1989). Verb lexis in the written compositions of young L2 learners. Studies in Second Language Acquisition, 11, 415-440.

HEINE, B. \& KUTEVA, T. (2005). Language Contact and Grammatical Change. Cambridge: CUP.

HICKMANN, M. (2006). The relativity of motion in first language acquisition. In M. Hickmann \& S. Robert (Eds.), Space in languages. Linguistic systems and cognitive categories (pp. 281-308.) Amsterdam: John Benjamins. 
A corpus-linguistic approach to transfer

HICKMANN, M. \& HENDRIKS, H. 2006). Static and dynamic location in French and English. First Language, 26(1), 103-135.

HOLMES, G. (1977). The problem of anglicized French at the university. Canadian Modern Language Review, 33(4), 520-531.

IACOBINI, C. \& MASINI, F. (2006). The emergence of verb-particle constructions in Italian: locative and actional meanings. Morphology, 16, 155-188.

JABERG, K. (1939). Quelques caractères généraux du Romanche. In Ch.-A. Sechehaye (Ed.), Mélanges de linguistique offerts à Charles Bally par des collègues, des confrères, des disciples reconnaissants. Genève: Georg.

JACKENDOFF, R. (2002). English particle constructions, the lexicon, and the autonomy of syntax. In N. Dehé et al. (Eds.), Verb-particle explorations (pp. 67-94). Berlin/New York: Mouton de Gruyter.

JANSSENS, R. (2001). Taalgebruik in Brussel. Taalverhoudingen, taalverschuivingen en taalidentiteit in een meertalige stad. Brussel: VUB Press.

JARVIS, S. (2000). Methodological rigor in the study of transfer: Identifying L1 influence in the interlanguage lexicon. Language Learning, 50, 245-309.

JARVIS, S. \& Pavlenko, A. (2008). Crosslinguistic influence in language and cognition. New York \& London: Routledge.

JONES, M. A. (1996). Foundations of French syntax. Cambridge: CUP.

JUDGE, A. \& HEALEY, F.G. (1985). A reference grammar of modern French. London: Edward Arnold.

KING, R. (2000). The semantic and syntactic reanalysis of lexical borrowings. Amsterdam/Philadelphia: Benjamins.

KING, R. (2008). Joual in context. Overview and evaluation of Acadie's joual. In 
G. Sankoff, , M. Meyerhoff \& N. Nagy (Eds.), Social lives in languagesociolinguistics and multilingual speech communities: celebrating the work of Gillian Sankoff (pp. 137-177). Amsterdam: Benjamins.

KOPECKA, A. (2006). The semantic structure of motion verbs in French. In M. Hickmann \& S. Roberts (Eds.), Space in languages: linguistic systems and cognitive categories (pp. 83-101). Amsterdam: John Benjamins.

KRAMER, J. (1981). Die Übernahme der deutschen und der niederlaendischen Konstruktion Verb + Verbzusatz durch die Nachbarsprachen. In W. Meid und K. Heller (Eds.), Sprachkontakt als Ursache von Veraenderungen der Sprachund Bewusstseinsstruktur. Innsbruck: Innsbrucker Beitraege zur Sprachwissenschaft.

LUMSDEN, J. F. (1999). Language acquisition and creolization. In M. Degraff (Ed.), Language Creation and Language Change. Creolization, Diachrony and Development. Learning, Development and Conceptual Change (pp. 129160). Cambridge MA: MIT Press.

MACWHINNEY, B. (2000). The Childes project: tools for analyzing talk. Mahwah, New Jersey: Lawrence Erlbaum Associates.

MAGNUS, I. (2007). La structure de la phrase en français et en néerlandais : comparaison des organisations syntaxique, sémantique et pragmatique, Revue Romane, 42(1), 80-102.

MALVERN, D. D., RICHARDS, B. J., CHIPERE, N. \& DURAN, P. (2004). Lexical Diversity and Language Development: Quantification and Assessment. Houndmills, Basingstoke: Palgrave Macmillan.

MARCHELLO-NIZIA, C. (2002). Prépositions françaises en diachronie. Lingvisticae Investigationes, 25(2), 205-221. 
MATRAS, Y. \& Sakel, J. (2004).Investigating the mechanisms of pattern replication In language convergence. Studies in Language, 31(4), 829-865.

MATRAS, Y. \& SAKEL, J. (2007). Grammatical borrowing in cross-linguistic perspective. Berlin/New York: Mouton de Gruyter.

MAYER, M. (1969). Frog where are you? New York : Dial books for young readers.

MEYER-LÜBKE, W. (1899). Grammatik der romanischen Sprachen. Darmstadt: Wissenschaftliche Buchgesellschaft.

MOUGEON, R, NADASDI, T. \& REHNER, K. (2005). Contact-induced linguistic innovations on the continuum of language use: the case of French in Ontario. Bilingualism: Language and Cognition 8(2), 2005, 99-115.

MOUGEON, R., BRENT, P., BÉLANGER, M. \& CICOCKI , W. (1980). Le français parlé en situation minoritaire. Vol. 1. Emploi et maitrise du français parlé par les élèves des écoles de langue française dans les communautés franco-ontariennes minoritaires. Toronto: Ontario Ministry of Education.

ROHLFS, G. (1983). Romanische Lehnübersetzungen aus germanischer Grundlage: materia romana, spirito germanico. München: Bayerische Akademie der Wissenschaften.

ROY, M.-M. (1979). Les conjonctions « but » et « so » dans le parler de Moncton. MA thesis. Université du Québec à Montréal.

SAKEL, J. (2007). Types of loan: Matter and pattern. In Y. Matras \& J. Sakel (Eds.), Grammatical borrowing in cross-linguistic perspective (pp.15-29). Berlin/New York: Mouton de Gruyter.

SCHLYTER, S. (1984). L'acquisition des verbes de déplacement/mouvement par des adultes suédois. Papers from the Institute of Linguistics, University of 
A corpus-linguistic approach to transfer

Stockholm (PILUS) 52.

SHARWOOD SMITH, M. \& KELLERMAN, E. (1986). Crosslinguistic influence in second language acquisition: an introduction. In E. Kellerman \& M. Sharwood Smith (Eds.), Crosslinguistic influence in Second Language Acquisition (pp. 1-9). New York etc.: Pergamon Institute of English.

SLOBIN, D. I. (2004). The many ways to search for a frog: linguistic typology and the expression of motion events. In S. Strömqvist \& L. Verhoeven (Eds.), Relating events in narrative: Vol 2. Typological and contextual perspectives, (pp. 219-257). Mahwah, NJ: Lawrence Erlbaum Associates.

TALMY, L. (1985). Lexicalization patterns: semantic structure in lexical forms. In: T. Shopen (Ed.), Grammatical categories and the lexicon. Volume III of Language typology and syntactic description (pp. 57-149). Cambridge: CUP.

TALMY, L. (2000). Toward a cognitive semantics, Vol I. Toward a Cognitive Semantics: Concept Structuring Systems. Cambridge MA: MIT Press.

THOMASON, S.G. \& KAUFMAN, T. (1988). Language contact, creolization and genetic linguistics. Berkeley etc.: University of California Press.

TREFFERS-DALLER, J. (1999). Borrowing and shift-induced interference: contrasting patterns in French-Germanic contact in Brussels and Strasbourg Bilingualism: Language and Cognition, 2(1), 1-22.

TREFFERS-DALLER, J. (in press). Operationalising and measuring language dominance. To appear in the International Journal of Bilingualism in 2011.

TREFFERS-DALLER, J. \& Tidball, F. (in prep.) Learnability and event construal among French learners of English and British learners of French.

TREMBLAY, M. (2005). Back en français acadien: archaïsme ou innovation ? In 
A corpus-linguistic approach to transfer

P. Brasseur \& A. Falkert (Eds.), Français d'Amérique: approches morphosyntaxiques (pp. 263-273). Paris: L’Harmattan.

TRUDGILL, P. (2004). The impact of language contact and social structure on

linguistic structure: Focus on the dialects of Modern Greek. In B. Kortmann (Ed.), Dialectology meets typology: Dialect Grammar from a cross-

linguistic perspective (pp. 435-451). Berlin: Mouton de Gruyter.

VEKEMANS, M. (1963). De invloed van de Brussels-Vlaamse volkstaal op de

Brussels-Franse volkstaal [The influence of the Brussels Dutch variety on the Brussels French variety]. Master thesis, Université Catholique de Louvain.

VINCENT, N. (1999). The evolution of C-structure: prepositions and PPs from Indo-

European to Romance. Linguistics, 37(6), 1111-1153.

YOUNG, H. (2002). C'est either que tu parles français, c'est either que tu parles anglais: A cognitive approach to Chiac as a contact language. $\mathrm{PhD}$ dissertation. Rice University. 
${ }^{\mathrm{i}}$ This variety is spoken by indigenous inhabitants of Brussels. According to De Vriendt and Willemyns (1987) it should be seen as separate from Belgian French. Brussels French is a variety of French that has phonetic, morphological, syntactic and lexical characteristics of its own, but the differences between Belgian French and Brussels French are not entirely clear cut: there is a continuum from those who display almost all characteristics of Brussels French in their speech to those who speak French with very few or hardly any of these characteristics.

${ }^{\text {ii }}$ Whether or not elements that are transferred from a source language are always fully integrated into the recipient language is an empirical question that cannot be addressed here. iii See Baetens Beardsmore (1971: 257) for a distinction between the "adverbes complets" and adverbs that correspond to Dutch "adverbes-pronoms".

iv The structure in (1a) is unusual in metropolitan French, as French does not have separate source prepositions to distinguish the different spatial relations expressed by from, out of and off in English. The preposition de is used in French to indicate the source of a movement (Jones 1996: 393). It is possible that tomber en dehors reflects the Dutch particle verb uitvallen "to fall out". In Dutch the expression fall out of a tree is widely used.

${ }^{\mathrm{v}}$ The word order in (20) could be influenced by Dutch, but in Frantext I have found one example of en bas after its complement: il étoit tombé de sa charette en bas "he fell from his cart down" (Charles de Mouhy (1735) La paysanne parvenue ou les Mémoires de Mme la Marquise de L.V., p. 356, Partie 11).

${ }^{\mathrm{vi}}$ It is important to point out that the collocation aller dehors and the verb sortir are not exact translation equivalents and can thus not be used interchangeably but the discrepancy between the frequencies of each clearly shows which of the two is the most common.

${ }^{\text {vii }}$ De Vriendt (pc) notes that in Brussels Dutch wei (standard Dutch weer) is often used instead of terug, but this is not imported into Brussels French either.

viii In Janssens' classification this group is to be distinguished from new bilinguals, that is those who have immigrated to Brussels from other parts of the country or abroad and brought their language varieties with them.

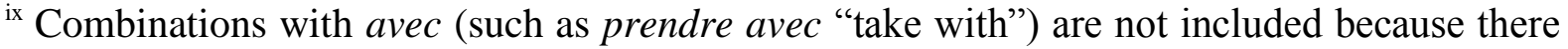
is such a large number of verbs that can be combined with this preposition/adverb, which makes it impossible to study it in the framework of this study. Collocations with avec will need to be dealt with separately.

${ }^{x}$ The TLFI provides one example of the combination of sortir and hors with a metaphorical meaning, namely sortir hors de soi « en colère " "to be beside oneself with anger" but the combination is not attested in the literal sense in this dictionary.

${ }^{\mathrm{xi}}$ In particular courir après was very frequent in the 18 th and $19^{\text {th }}$ century (472 and 785 examples) respectively. Checking a representative sample was deemed sufficient.

${ }^{x i i}$ If the two collocations which are attested in the TLFI (courir après and crier après) are omitted from the analysis, the differences between the groups remain significant $(\mathrm{F}(2,72)$ $=15.69, \mathrm{p}<.001)$. A Tukey post-hoc analysis reveals that the Brussels group is still significantly different from the two other groups if these two verbs are not included. xiii Calculating the relative frequency of the collocations in these two groups did not seem necessary as it is clear it is close to zero.

${ }^{\text {xiv }}$ One reviewer suggests speakers might use invectiver "hurl, shout abuse at" instead of crier après, but this is not the meaning of the expression crier après in the frog stories. It is used for the instances in which the boy calls for his frog. 
${ }^{\mathrm{xv}}$ It is a little surprising that the collocations which are attested in the TLFI (courir après and crier après) do not appear in this corpus at all. A possible reason for this could be that there are so few occurrences of courir and crier in this corpus, and thus there are hardly any opportunities for collocations based on these two verbs to occur. In a larger corpus these would probably have been found.

${ }^{x v i}$ According to De Vriendt (pc) it is possible to use regarder pour in a different meaning (not seek), as in il faudrait aussi regarder pour des piles "We have to see if there are any batteries availabl"e in Brussels French. In the current corpus this usage was not found.

${ }^{x v i i}$ Although it is difficult to determine in many cases whether a particular sentence from the Sketchengine corpus originates with a speaker from metropolitan French or with speakers of other varieties, there is no evidence that the data used here are from speakers of varieties of French that were influenced by Germanic varieties.

xviii As there are only four occurrences of the verb courir in the corpus, it is not possible to calculate the relative frequency of the VPC in this case.

${ }^{x i x}$ Regarder après and demander après have been left out of Figure 1 to simplify it, as the curve is identical with that of chercher après.

${ }^{x x}$ In this scene, Alidor has promised his friend Cléandre, who is in love with Angélique, to give her a letter in which he promises to marry her. But in reality the letter is signed by Cléandre, not Alidor. They are both afraid she may discover the plot and scream when she discovers she has been deceived, because the two men do not look like each other.

${ }^{x x i}$ According to De Vriendt (pc) the rennen is exogenous in Flanders. Instead lopen is used to express the concept of "rennen".

xxii There are many Dutch translation equivalents for sortir dehors, as this expression can be used transitively as well as intransitively. In Dutch, different verbs are used to express the range of meanings of sortir dehors: intransitive: (naar) buiten gaan or uitgaan; transitive: buiten zetten, buiten laten, uitlaten, withalen, etc. Calculating the relative frequency of the Dutch translation equivalents of sortir dehors is therefore hardly possible, and such calculations have not been included in Table 7 .

xxiii In the latter case there is a slight meaning difference in Standard Dutch: iets naar iemand roepen means "to shout something at someone", whereas iemand roepen means "to call (for) someone". 